JURNAL INFOMANPRO

p-ISSN 2460-9609

e-ISSN 2774-7956

https://ejournal.itn.ac.id/index.php/infomanpro

vol.10 No2 Tahun 2021, pp.11-18

\title{
PROTOTIPE SDOF DENGAN MENGGUNAKAN MIKROKONTROLER SEBAGAI PENGUKURAN TUMBUKAN ANTAR STRUKTUR BANGUNAN
}

\author{
Vega Aditama1, Bambang Wedyantadji² \\ 1,2Prodi Teknik Sipil, ITN Malang, Jl. Bendungan Sigura-gura No $2 A$.
}

\begin{abstract}
ABSTRAK
Gempa bumi berdampak pada perilaku gerakan dinamis pada struktur bangunan. Bangunan yang memiliki perbedaan bentuk, ketinggian, dan bahan konstruksi yang berbeda menimbulkan gerakan yang berbeda dari modeshape dan juga drift bangunan tersebut. Perlu memastikan bahwa tumbukan antar bangunan bisa terjadi dengan menggunakan pemodelan MDOF dengan prototipe dengan gerak dinamis akibat percepatan dasar. Dengan menggunakan mikrokontroler Arduino modul akselerasi dan peralatan yang dimodifikasi untuk membuat meja getar maka untuk memperoleh perpindahan antar lantai / pendulum MDOF dapat diketahui .
\end{abstract}

Kata kunci: Tumbukan Bangunan, MDOF, Prototip

\section{PENDAHULUAN}

Perencanaan yang baik untuk struktur bangunan adalah merencanakan dengan menghitung kekuatan struktur, menyesuaikan kebutuhan penghuni, sampai pada mengatisipasi dampak yang terjadi ketika gedung tersebut terkena dampak kerusakan struktur. Kerusakan struktur bangunan lazimnya terjadi ketika adanya gempa bumi yang mengakibatkan adanya kontak antar elemen bangunan sehingga terjadi benturan dan kerusakan pada kolom dan dinding bangunan tersebut.

Kolom atau dinding geser yang mengalami defleksi akibat pergerakan oleh karena akselerasi gempa, tidak secara jelas terlihat dikarenakan adaa beberapa faktor antara lain, gedung yang tidak terlalu tinggi, gaya gempa yang kecil dan kolom yang memiliki kekakuan yang besar.

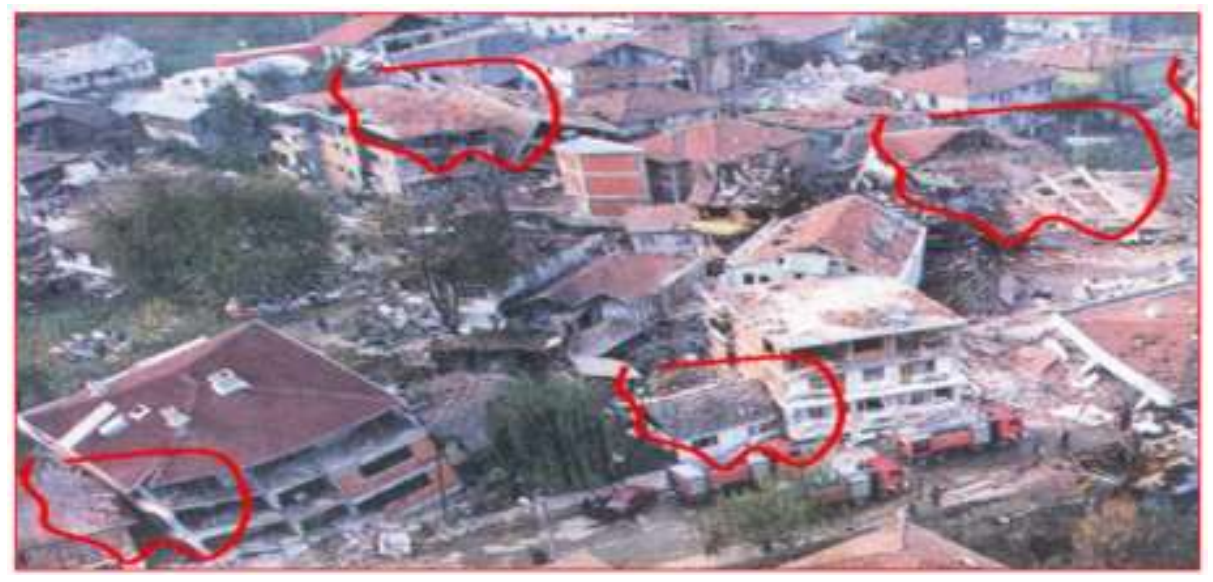

Gambar 1. Gedung gedung yang mengalami kontak setelah terjadi gempa

Kontak antar gedung setelah atau saat terjadi gempa bisa saja terjadi berkali kali , dikarenakan masing masing struktur bangunan yang memiliki kekakuan kolom yang berbeda, dan adanya lokasi pelat lantai yang mengenai midspan pad kolom. Sehingga kerusakan akan terjadi semakin hebat.

Perlu adanya sebuah penelitian yang membuktikan bahwa adanya pengaruh dari kekakuan, gap (jarak antar bangunan), massa ataupun percepatan gempa pada besar kecilnya tumbukan ( pounding) yang terjadi. Sehingga bisa dilakukan kajian yang lebih mendalam lagi terkait mitigasi akibat gedung yang saling berdekatan 


\section{JURNAL INFOMANPRO}

p-ISSN 2460-9609

e-ISSN 2774-7956

https://ejournal.itn.ac.id/index.php/infomanpro

vol.10 No2 Tahun 2021 , pp.11-18

\section{Teori tentang SDOF}

Sistem yang dipertimbangkan ditunjukkan secara skematis pada Gambar 1.2.1. Ini terdiri dari massa $\mathrm{m}$ yang terkonsentrasi di tingkat atap, bingkai tanpa massa yang memberikan kekakuan pada sistem, dan peredam kental (juga dikenal sebagai dashpot) yang menghilangkan energi getaran sistem. Balok dan kolom diasumsikan tidak dapat diperpanjang secara aksial. Sistem ini dapat dianggap sebagai idealisasi struktur satu lantai. Setiap bagian struktur (balok, kolom, dinding, dll.) dari struktur sebenarnya memberikan kontribusi terhadap sifat inersia (massa), elastis (kekakuan atau fleksibilitas), dan disipasi energi (redaman) dari struktur. Namun, dalam sistem yang diidealkan, masing-masing properti ini terkonsentrasi

Dalam tiga komponen murni yang terpisah: komponen massa, komponen kekakuan, dan redaman komponen. Jumlah perpindahan independen yang diperlukan untuk menentukan posisi perpindahan semua massa relatif terhadap posisi aslinya disebut jumlah derajatkebebasan (DOF) untuk analisis dinamis. Lebih banyak DOF biasanya diperlukan untuk didefinisikan sifat kekakuan struktur dibandingkan dengan DOF yang diperlukan untuk merepresentasikan sifat inersia. Perhatikan kerangka satu lantai pada Gambar 2, dibatasi hanya untuk bergerak ke arah eksitasi. Masalah analisis statis harus dirumuskan dengan tiga DOF - perpindahan lateral dan dua rotasi sendi — untuk menentukan kekakuan lateral rangka. Sebaliknya, struktur hanya memiliki satu DOF — lateral perpindahan - untuk analisis dinamis jika diidealkan dengan massa yang terkonsentrasi di satu lokasi, biasanya di tingkat atap. Jadi kami menyebutnya sistem derajat kebebasan tunggal (SDF).

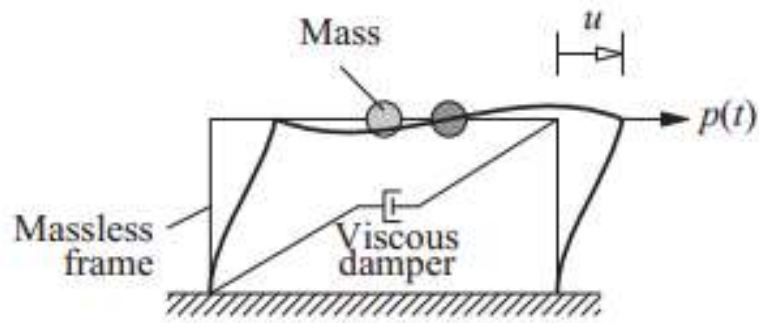

(a)

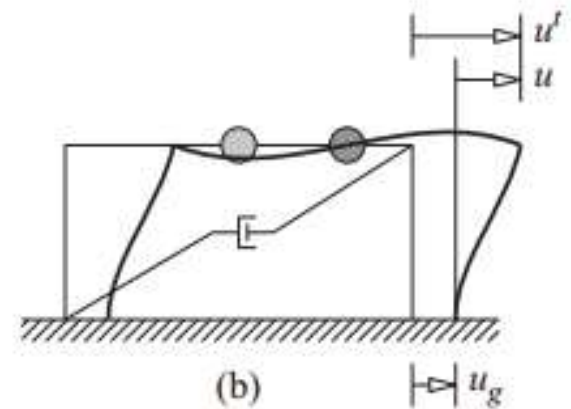

(b)

Gambar 2. a.) SDOF ketika ada beban $P$ b.) SDOF ketika ada beban gempa

Gaya-gaya yang bekerja pada massa pada waktu tertentu ditunjukkan pada Gambar 4b. Ini termasuk gaya eksternal $p(t)$, gaya penahan elastis (atau inelastis) fS (Gbr. 1.3.1), dan gaya penahan redaman $f D$ (4b). Kekuatan eksternal dianggap positif arah sumbu $\mathrm{x}$, dan perpindahan $\mathrm{u}(\mathrm{t})$, kecepatan $\mathrm{u}^{*}(\mathrm{t})$, dan percepatan $\mathrm{u}^{*}(\mathrm{t})$ searah sumbu $x$ juga positif. Gaya elastis dan redaman ditampilkan

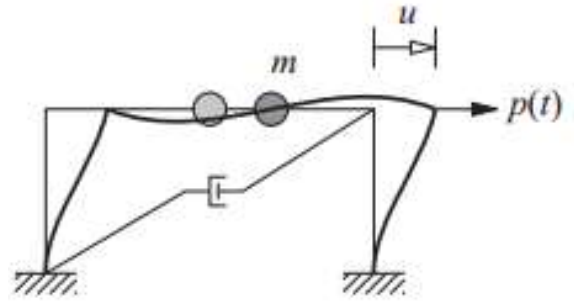

(a)

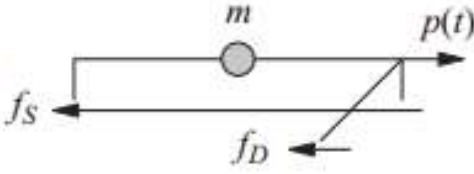

(b)

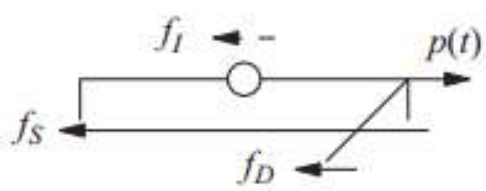

(c)

Gambar 3. Gaya Eksternal yang mengakibatkan perpindahan

Makalah dapat ditulis baik dalam bahasa Indonesia maupun Inggris. Tulisan dalam pokok uraian menggunakan jenis huruf Times New Roman ukuran 10 pt, justified, 1 spasi, sebagaimana pada dokumen ini. Penulis diperbolehkan menggunakan huruf jenis lain untuk keperluan khusus misalnya untuk membedakan source code suatu program komputer.

Judul dari suatu section (heading dari section) ditulis dengan Times New Roman Capital 11pt, bold. Penomoran dimulai dengan angka 1, 2, 3, dst. Format paragraf justified, dan dalam satu halaman diusahakan rata atas dan bawah, sehingga sisa spasi dapat diatur oleh penulis. Penggantian alinea diberi jarak 1 spasi. 
JURNAL INFOMANPRO

p-ISSN 2460-9609

e-ISSN 2774-7956

https://ejournal.itn.ac.id/index.php/infomanpro

vol.10 No2 Tahun 2021 , pp.11-18

\section{Teori tentang Arduino}

Arduino adalah komponen mikrokontroler yang merupakan pemroses dari data analog sensor menuju ke data digital. Terdapat beberapa macam arduino yang sudah tersedia secara komersil, namun yang memiliki kemampuan dalam transmisi data secara wireless adalah arduino jenis ESP 6288 D1 wemos wifi.

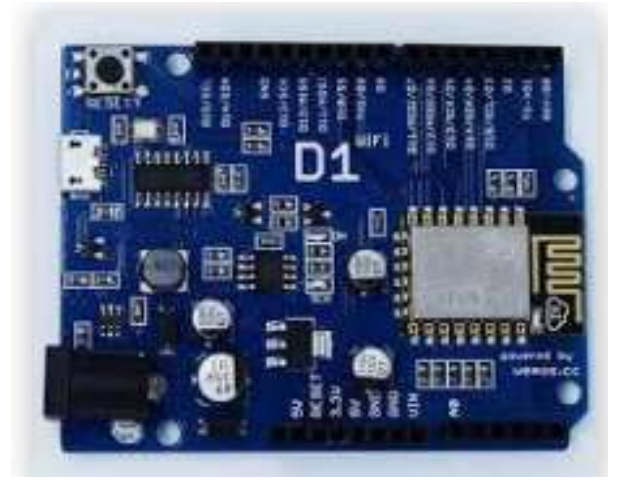

Gambar 4. Arduino ESP 6288 D1 wemos wifi

Sensor akselero meter merupakan sensor yang mengukur percepatan secara linear dalam 3 sumbu, dengan resolusi yang mencapai 13 bit dan rang percepatannya adalah diantara $2 \mathrm{~g}-16 \mathrm{~g}(1 \mathrm{~g}=9,81 \mathrm{~m} / \mathrm{s} 2)$

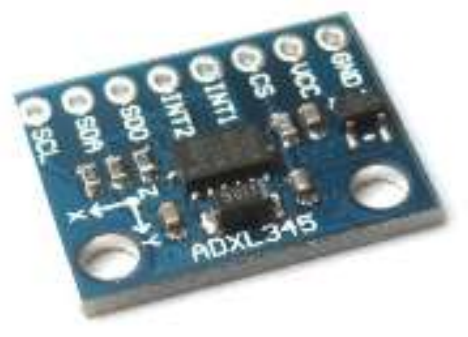

Gambar 5. Modul Accelerometer ADXL345 3-axis

Penilitian tentang SDOF telah dilakukan oleh Qichao Xue, dkk dari College of Aerospace and Civil Engineering, Harbin Engineering University, Harbin, China pada tahun 2017. Makalah ini berfokus pada kinerja kontrol getaran Pounding Tuned Massed Damper (PTMD) dengan lapisan viskoelastik pounding, yang dapat menghilangkan energi selama proses tumbukan. Dengan menggunakan metode analisis gaya hantaman viskoelastik, dua jenis model gaya hentakan untuk geometri kontak yang berbeda dikembangkan untuk menggambarkan interaksi antar komponen hentakan di PTMD. Uji meja goyang berdasarkan struktur eksperimental yang disederhanakan dilakukan untuk memverifikasi keefektifan PTMD tunggal serta model gaya hentakan viskoelastik. Selanjutnya, studi parametrik untuk struktur baja 14 lantai disajikan untuk mengetahui kinerja perangkat PTMD dalam sistem multiple degree offreedom (MDOF). Hasil dari simulasi numerik menunjukkan bahwa material viskoelastik yang tepat dan celah antara blok massa dan pembatas di PTMD merupakan faktor kunci untuk kinerja kontrol getaran. Dengan memasukkan serangkaian eksitasi seismik ke dalam sistemMDOF, perbandingan antara PTMD dan TMD tradisional mengungkapkan bahwa PTMD yang dioptimalkan memiliki kinerja yang lebih baik daripada TMD tradisional dalam peredaman getaran pada kasus tertentu. 


\section{JURNAL INFOMANPRO}

p-ISSN 2460-9609

e-ISSN 2774-7956

https://ejournal.itn.ac.id/index.php/infomanpro

vol.10 No2 Tahun 2021 , pp.11-18

Penelitian selanjutnya oleh Mahmoud Miari, dkk dari School of Civil Engineering, Universiti Sains Malaysia, Malaysia pada tahun 2019. Makalah ini berfokus pada tumbukan struktural pada bangunan. Penumbukan struktural telah diamati di banyak gempa bumi sebelumnya karena celah yang tidak mencukupi yang biasanya disediakan antara bangunan yang berdekatan. Tabrakan biasanya menghasilkan gaya benturan yang besar dan pulsa percepatan berdurasi pendek yang dapat mengakibatkan kerusakan signifikan pada bangunan yang bertabrakan. Karena itu, hempasan struktural akibat gempa telah dipelajari dan diselidiki secara intensif selama tiga dekade terakhir. Hasil dari beberapa investigasi ini sesuai, sedangkan yang lain bertentangan. Karya ini mengulas studi penelitian sebelumnya tentang penumbukan struktural akibat gempa yang bertujuan untuk lebih memahami fenomena hentakan itu sendiri dan alasan di balik hasil yang bertentangan. Efek hantaman pada bangunan dengan basis tetap, bangunan terisolasi, dan bangunan yang bertumpu pada tanah lunak dibahas. Kemudian, aspek kesenjangan yang direkomendasikan cukup dipertimbangkan. Langkah-langkah mitigasi yang tepat juga ditangani dan arah studi penelitian masa depan tentang penumbukan struktural direkomendasikan.

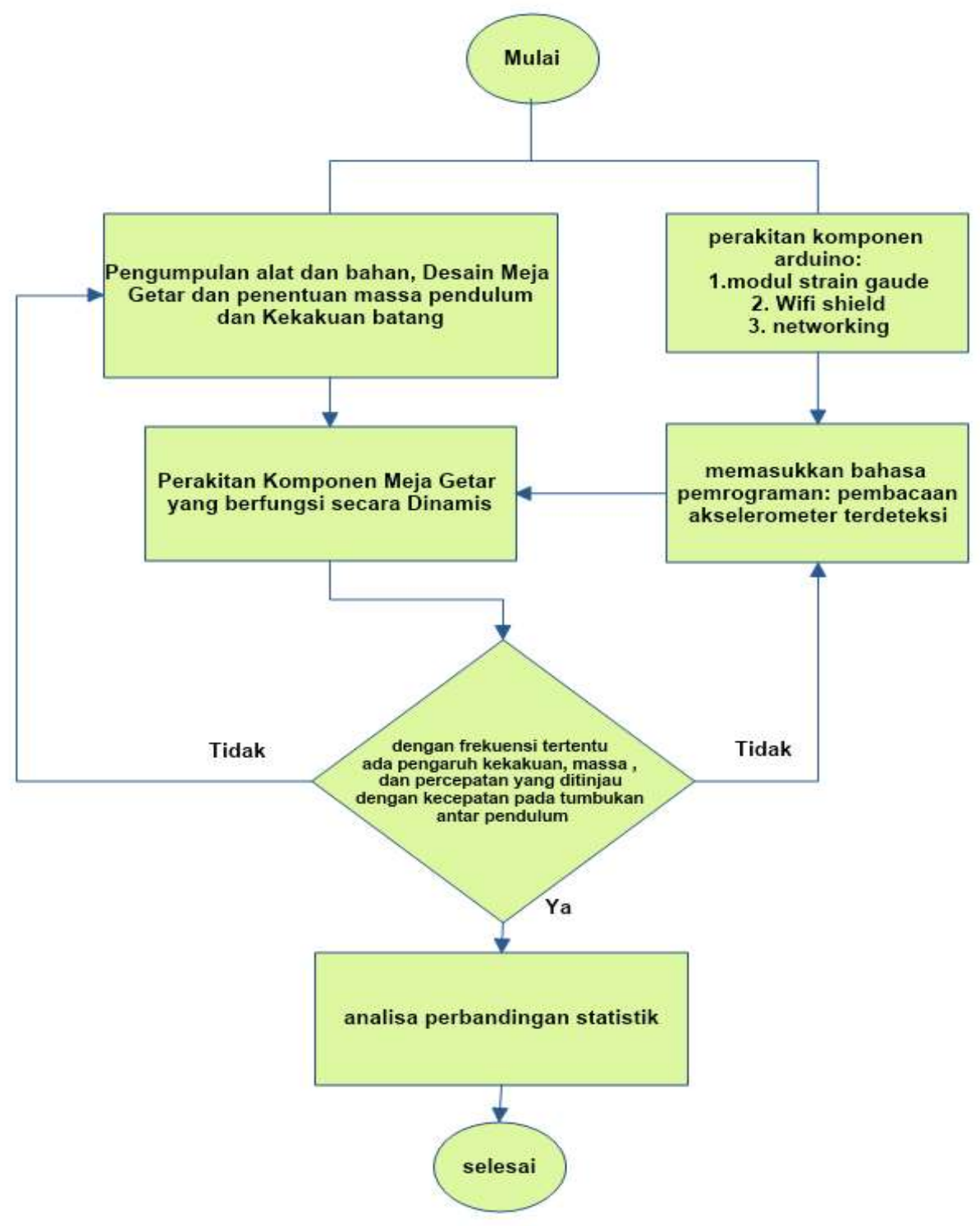

Gambar 6. Diagram Alir Metode Penelitian 


\section{JURNAL INFOMANPRO}

p-ISSN 2460-9609

e-ISSN 2774-7956

https://ejournal.itn.ac.id/index.php/infomanpro

vol.10 No2 Tahun 2021, pp.11-18

Akselerometer digunakan untuk mengukur gaya yang dihasilkan selama percepatan. Yang paling mendasar adalah percepatan gravitasi yang umum dikenal yaitu $1 \mathrm{~g}$. Dengan mengukur percepatan yang disebabkan oleh gravitasi, Anda dapat menghitung sudut kemiringan perangkat ke permukaan yang rata. Dengan menganalisis akselerasi dinamis, Anda dapat mengetahui cara perangkat bergerak. Misalnya, self balancing board atau hoverboard menerapkan sensor percepatan dan giroskop untuk filter Kalman dan koreksi postur.

ADXL345 adalah akselerometer 3 sumbu kecil, tipis, berdaya rendah, dengan resolusi tinggi (13-bit) hingga $\pm 16 \mathrm{~g}$. Data keluaran digital diformat sebagai pelengkap 16-bit dua dan dapat diakses melalui antarmuka digital SPI (3- atau 4-kabel) atau I2C. Dalam percobaan ini digunakan antarmuka digital I2C. Ini sangat cocok untuk mengukur akselerasi statis gravitasi dalam aplikasi sensor kemiringan, serta akselerasi dinamis yang dihasilkan dari gerakan atau guncangan. Resolusi tingginya (4 mg / LSB) memungkinkan pengukuran perubahan kemiringan kurang dari 1,0 ○. Dan sensitivitas yang sangat baik (3.9mg / LSB @ $2 \mathrm{~g}$ ) memberikan output presisi tinggi hingga $\pm 16 \mathrm{~g}$.

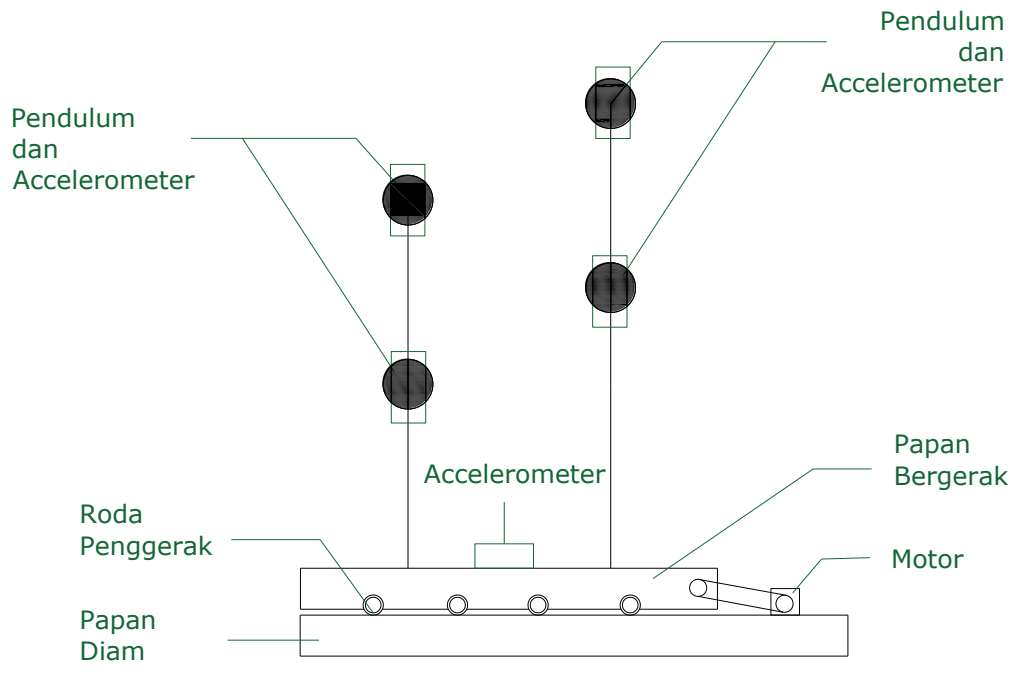

Gambar 7. Rangkaian komponen pengujian 1

Perelatan yang digunakan yaitu C - Beam Linear Actuator / Slider Table Bundle Kit CNC Travel 400mm dengan Panjang Total $61 \mathrm{Cm}$, Travel $40 \mathrm{~cm}$, Lead $2 \mathrm{~mm}$, Nema motor 1.3Nm . Stepper yang digunakan adalah yang mampu hingga 3,5 Ampere yaitu stepper motor drive 32 segments TB6600 4.0A 42VDC

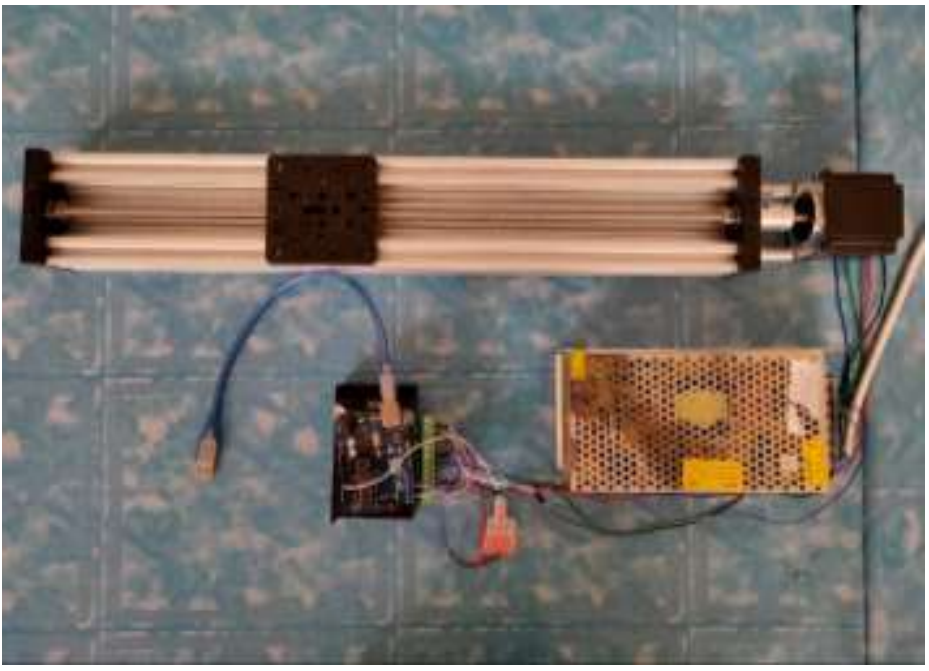

Gambar 6. Pemasangan Setelah Arduino dan Komponennya dirakit dan Program dimasukkan 


\section{JURNAL INFOMANPRO}

p-ISSN 2460-9609

e-ISSN 2774-7956

https://ejournal.itn.ac.id/index.php/infomanpro vol.10 No2 Tahun 2021 , pp.11-18

Setelah itu dipasang batang dan pendulum yang akan digunakan sebagai uji Getaran.Terlebih dahulu batang dicek besar diameternya dan pendulum di timbang dulu beratnya.

\section{Hasil dan Pembahasan}

Aplikasi Staad Pro bisa digunakan untuk melihat simpangan antar struktur dengan menggunakan metode input yang benar, termasuk dalam perencanaan geometri. Batang yang digambar dengan menggunakan snap node harus menyesuaikan tinggi batang yang ditentukan pada tabel 1 .

Tabel 1. Rancangan Frekuensi dan Massa sebelum dilakukan penggetaran

\begin{tabular}{|c|c|c|c|c|c|c|c|c|}
\hline \multirow{2}{*}{$\begin{array}{c}\text { Tinggi per } \\
\text { lantai }(\mathrm{cm})\end{array}$} & \multirow{2}{*}{$\begin{array}{c}\text { Tumggi total } \\
(\mathrm{cm})\end{array}$} & \multicolumn{3}{|c|}{ Frequensi (Hz) } & \multicolumn{3}{c|}{ Massa Lantai (gr) } \\
\cline { 4 - 9 } & & & 1 & 2 & 3 & 1 & 2 & 3 \\
\hline 20 & 2 & 40 & 4 & 5 & 6 & 50 & 100 & 150 \\
\hline 30 & 2 & 60 & 4 & 5 & 6 & 50 & 100 & 150 \\
\hline 30 & 2 & 60 & 4 & 5 & 6 & 50 & 100 & 150 \\
\hline
\end{tabular}

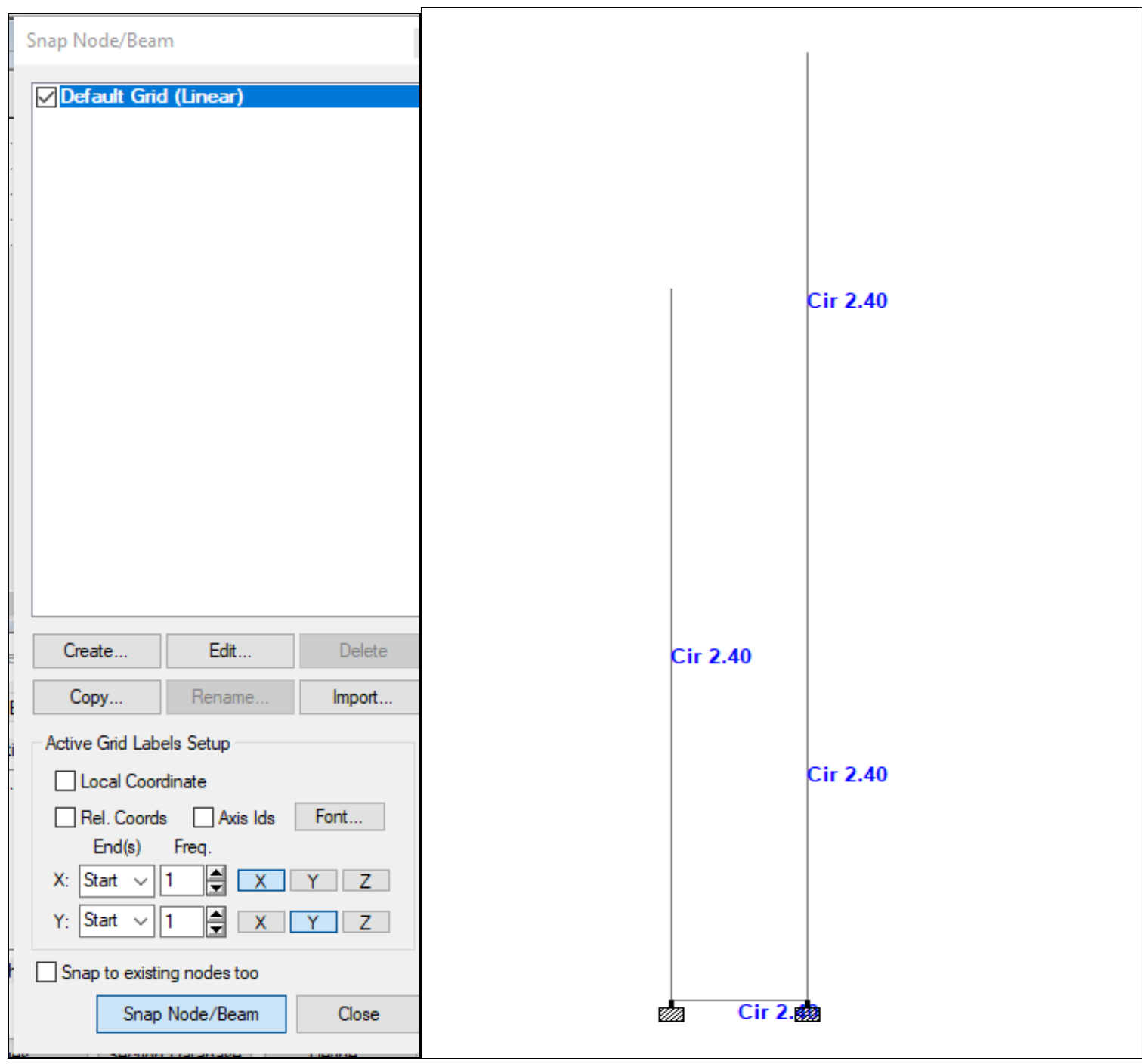

Gambar 7. Perancangan Geometri SDOF pada Staad Pro 


\section{JURNAL INFOMANPRO \\ p-ISSN 2460-9609 \\ e-ISSN 2774-7956}

https://ejournal.itn.ac.id/index.php/infomanpro

vol.10 No2 Tahun 2021 , pp.11-18

Setelah membuat Geometri pada Staadpro, maka saatnya mendefinisikan penampang dan material pembentuk. Penampang yang dipakai adalah berbentuk silinder $6 \mathrm{~mm}$ dengan panjang sesuai tabel 1. Namun dalam pemodelan karena dalam staad pro struktur yang di analisis harus jadi 1 , maka dmasing masing tumpuan dijadikan 1 dengan penghubung.

Pengujian dilakukan secara bertahap sesuai dengan ketentuan perancangan yang sama dengan data awal analisa. Pada gambar 10 diperlihatkan kondisi ketika SDOF belum digetarkan. Pada gambar 11 diperlihatkan kondisi ketika 2 Batang SDOF dengan jarak $2 \mathrm{~cm}$ mengalami tumbukan.
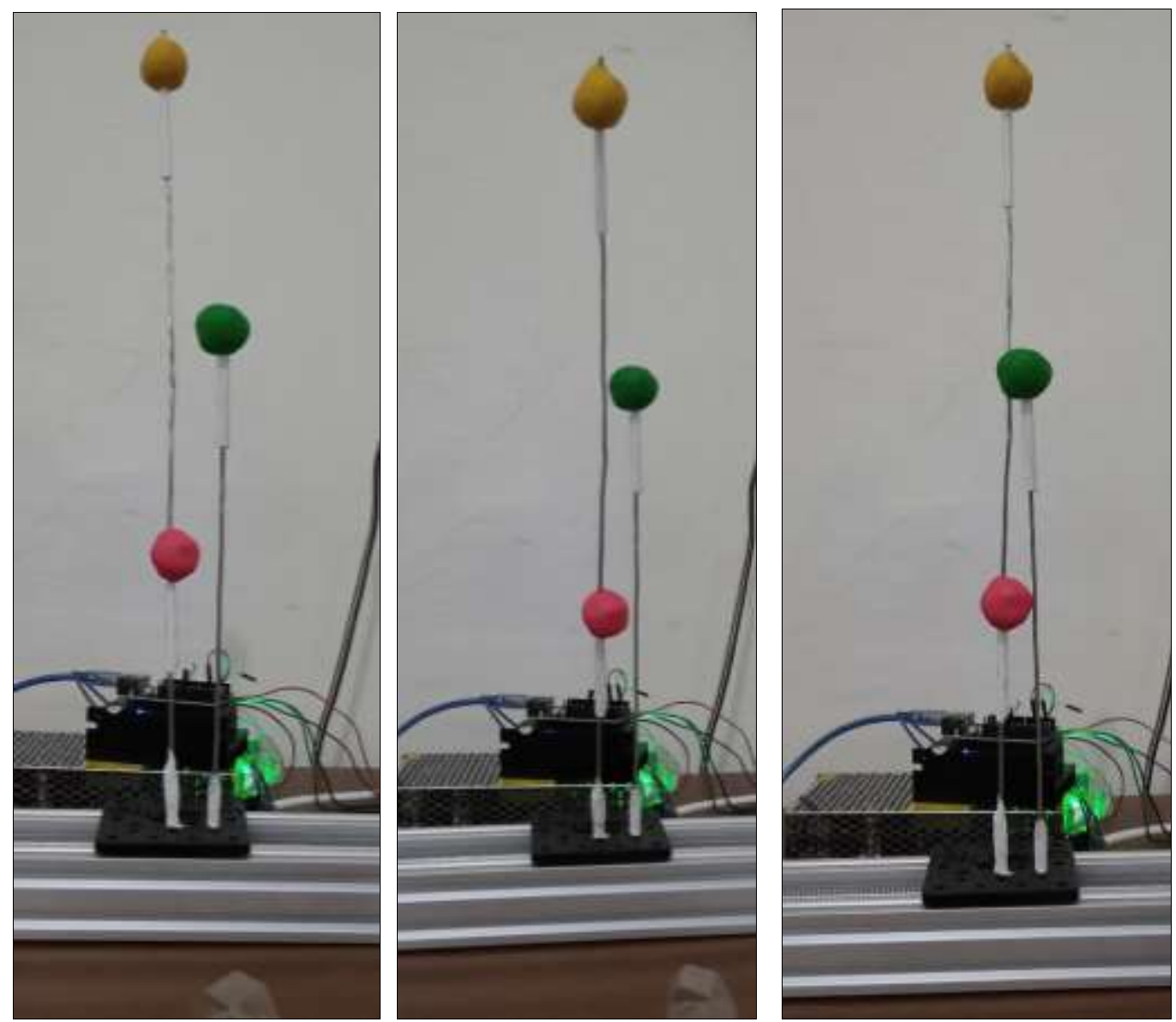

Gambar 8. Pengujuan Prototipe SDOF dengan frekuensi bertahap

Dari rangkaian alat mikrokontroler yang digunakan berfungsi dengan baik menghasilkan frekuensi mulai dari yang 0 sanpai dengan $6 \mathrm{~Hz}$. Setelah digetarkan dengan pemodelan getaran tak teredam, maka didapatkan hasil pengukuran simpangan menggunakan alat ukur penggaris dan akselerometer yang ditunjukkan pada tabel 2, bahwa dalam jarak gap $2 \mathrm{~cm}$ simpangan yang terjadi dalam beberapa kondisi dari massa jenis dan kekakuan struktur mengalami simpangan mulai dari $1,5 \mathrm{~cm}$ sampai dengan $3,2 \mathrm{~cm}$.

Tabel 2. Hasil Simpangan SDOF dari Pengujian

\begin{tabular}{|c|c|c|c|}
\hline Tinggi $(\mathrm{cm})$ & Massa per Lantai (gr) & Frequensi & Simpangan $(\mathrm{mm})$ \\
\hline 60 & 50 & 4 & 15 \\
\hline 40 & 50 & 4 & 17 \\
\hline
\end{tabular}


JURNAL INFOMANPRO

p-ISSN 2460-9609

e-ISSN 2774-7956

https://ejournal.itn.ac.id/index.php/infomanpro

vol.10 No2 Tahun 2021 , pp.11-18

\begin{tabular}{|c|c|c|c|}
60 & 100 & 4 & 23.5 \\
\hline 60 & 50 & 5 & 21 \\
\hline 40 & 50 & 5 & 26 \\
\hline 60 & 100 & 5 & 28.5 \\
\hline 60 & 50 & 6 & 28 \\
\hline 40 & 50 & 6 & 31 \\
\hline 60 & 100 & 6 & 32 \\
\hline
\end{tabular}

\section{KESIMPULAN}

Dari Penelitian ini dapat disimimpulkan terjadinya tumbukan antar bangunan pada GAP yang kecil bahkan berhimpitan bisa terjadi karena perbedaan kekakuan struktur dan massa antar lantai yang dibuktikan dengan penelitian SDOF. Pada struktur yang tidak terlalu tinggi frekuensi getaran yang besar akan menambah nilai simpangan daripada struktur yang tinggi. Sedangakan massa lantai struktur mempengaruhi besarnya simpangan lantai tersebut

\section{DAFTAR PUSTAKA (DAN PENULISAN PUSTAKA)}

Adhikary, S. D., Li, B., \& Fujikake, K. (2015). Low Velocity Impact Response of Reinforced Concrete Beams: Experimental and Numerical Investigation. International Journal of Protective Structures, 6(1), 81-111. https://doi.org/10.1260/2041-4196.6.1.81

Jankowski, R., \& Mahmoud, S. (2015). Earthquake-Induced Structural Pounding. Springer International Publishing. https://doi.org/10.1007/978-3-319-16324-6

Łodygowski, T., \& Rusinek, A. (Eds.). (2014). Constitutive Relations under Impact Loadings (Vol. 552). Springer Vienna. https://doi.org/10.1007/978-3-7091-1768-2

Polycarpou, P. C., Komodromos, P., \& Polycarpou, A. C. (2013). A nonlinear impact model for simulating the use of rubber shock absorbers for mitigating the effects of structural pounding during earthquakes: A NEW IMPACT MODEL FOR SIMULATING THE USE OF RUBBER SHOCK ABSORBERS. Earthquake Engineering \& Structural Dynamics, 42(1), 81-100. https://doi.org/10.1002/eqe.2194

Aditama, V., \& Wedyantadji, B. (n.d.). Deteksi Jarak Jauh Kegagalan pada Beton Bertulang Berbasis Arduino. 7.

Anagnostopoulos, S. A. (2004). Equivalent viscous damping for modeling inelastic impacts in earthquake pounding problems. Earthquake Engineering \& Structural Dynamics, 33(8), 897-902. https://doi.orq/10.1002/eqe.377

Saatci, S., \& Vecchio, F. J. (2005). Finite Element Analysis of Shear-Critical Reinforced Concrete Beams Under Impact Loading. 9.

Hu, G., Wang, Y., Huang, W., Li, B., \& Luo, B. (2020). Seismic mitigation performance of structures with viscous dampers under near-fault pulse-type earthquakes. Engineering Structures, 203, 109878.

https://doi.org/10.1016/j.engstruct.2019.109878

Wu, Z., Ma, T., Jiang, H., \& Jiang, C. (2013). Multi-scale seismic hazard and risk in the China mainland with implication for the preparedness, mitigation, and management of earthquake disasters: An overview. International Journal of Disaster Risk Reduction, 4, 21-33. https://doi.org/10.1016/j.ijdrr.2013.03.002

Purwowibowo, P., \& Prasasti, N. R. (2018). Desain Akselerometer Menggunakan Mikrokontroler Arduino Due. Instrumentasi, 41(1), 35. https://doi.org/10.14203/instrumentasi.v41i1.145 